\title{
Jeg Husker DEg, John Aage ...
}

Siste gang jeg så deg, John Aage, var den 28. mars i fjor. Det var sent på kvelden og vi satt på kaféen til det tidligere Lenin Museum i byen Krasnojarsk i det indre av Sibir. Vår venn Vladimir, leder for organisasjonen Memorial, hadde lenge fortalt oss om Sibirs tragiske fortid, og om sitt trøstesløse arbeid med å redde minnene fra GULAG-øyriket fra glemselen, som hadde hatt så stor utstrekning her i regionen. Jeg så på deg, og jeg skjønte at du følte som meg, at meningen med det internasjonale samarbeidet nå hadde fătt en ny dimensjon, at det var en forpliktelse å engasjere seg og hjelpe til med dokumentasjonen av de mørke sidene ved det 20. århundrets historie.

Dagen etter tok jeg flyet tilbake til Oslo. Du skulle komme etter ett par uker senere. Den 6. april, kl. 6 om morgenen, ringte telefonen fra Krasnojarsk, og de sa at du var død, at det hadde skjedd brått, for bare en time siden ... Våre venner fra Krasnojarsk fortalte meg senere at du kvelden før hadde hatt en lang samtale med en mann derfra som under krigen, som barn, hadde levd sammen med sin mor i en tysk arbeidsleir ved Kirkenes. De sa at du hadde kommet fra dette møtet meget berørt, og at det kanskje var det som hadde "knust ditt hjerte" ...

Jeg husker godt første gang jeg så deg, John Aage. Det var under Museumsforbundets årsmøte på Røros i 1977. Som følge av innføring av tilskuddsordningen et stort vendepunkt for de norske museene - hadde en ny generasjon av konservatorer her gjort sin entré på museumsscenen. Du var da 24 år gammel og nylig ansatt som bestyrer av Toten Museum. Jeg kjente deg ikke, men jeg ble oppmerksom på deg. Du sto midt i en gruppe, og argumenterte intenst og gestikulerende, med et engasjement og en energi som du beholdt helt til slutt. Dette bildet er for meg blitt stående som symbol på fornyelsen som skulle prege det norske museumssystemet $\mathrm{i}$ de påfølgende årene. En fornyelse der du spilte en aktiv rolle, både som ideolog, praktiker og debattant.

Du hadde begynt å arbeide på Toten Museum lenge før du ble ansatt som bestyrer. Du var fra Toten og allerede i 1960-årene, hadde du som barn, skaffet deg variert praksis fra museumsarbeid. Fra begynnelsen av 1980-tallet omdannet du det 
94 gamle museet på Toten til en institusjon som etterhvert fikk internasjonalt ry for sitt banebrytende arbeid: Toten Økomuseum. Her var museumsarbeidet blitt et aktivt bindeledd mellom fortid, nåtid og framtid. Gjennom systematisk dokumentasjon og formidling ble lokalbefolkningen trukket inn som deltaker.

Jeg husker et seminar på Toten i 1987, da du med stolthet presenterte museet til Hugues de Varine, den store pionier av de franske "écomuseene". Jeg husker også den energi du la inn i opprettelse og drift av den Norske Gruppe av Økomuseer, som samlet kolleger som delte vårt syn, og som spilte en sentral rolle som forum og nettverk for utvikling av nye museumsmodeller.

Samtidig begynte du å engasjere deg i det internasjonale museumssamarbeidet. Jeg husker deg fra en mottakelse i en park i Greenwich ved London, under ICOMs Generalkonferanse i 1983, der du snakket med stor intensitet med tolken til den kinesiske delegasjonen. Det var første gang du deltok på en internasjonal konferanse, som nyvalgt medlem i Norsk-ICOMs styre. Dette var begynnelsen på et mangfoldig og fruktbart internasjonalt engasjement, der du spilte aktive roller somt blant annet styremedlem i ICOMs internasjonale komité, ICR Regional Museums i 1980årene og ICOFOM Museology i 1990-årene.

Jeg husker deg som skribent og redaktør, en aktivitet du hadde spesielt stort talent for, først foran en enorm datamaskin som fylte det meste av ditt arbeidsrom, og som etterhvert ble erstattet av et imponerende antall Mac'er av forskjellige modeller. Jeg husker ditt arbeid med Museumsnytt i 1980-årene, som ble omdannet til et innsiktsfylt informasjons- og debattorgan. I 1990-årene ble Nordisk Museologi ditt hjertebarn; du investerte på mange forskjellige måter mye engasjement og kreativitet i dette tidsskriftet, et verk som du med rette var spesielt stolt av.

I 1991 forlot du Toten Økomuseum for å arbeide med forskjellige prosjekter i Norge og i utlandet. Du begynte å studere museologi som doktorgradstudent ved universitetet i Umeå. Din doktoravhandling, som bygde på en original studie av utviklingen av kulturverntanken på Røros, ble dessverre aldrig ferdig; til det hadde du engasjert deg for sterkt i for mye.

Du ble samtidig spesialist i museumsplanlegging på frilansbasis. Det var ikke få prosjekter i Norge i 1990-årene, både store og små, som dro stor nytte av dine faglige og strategiske evner. Denne virksomheten kulminerte med åpning av Ivar Aasen-tunet/Nynorsk kultursentrum sommeren 2000, realisert i samarbeid med den store arkitekt Sverre Fehn. 
Jeg har mange minner, John Aage, fra vårt samarbeid over en lang periode. Det fineste er kanskje det jeg opplevde under herlige høst-dager i 2000, da vi var sammen med en gruppe kinesere som var på besøk i Norge. Det var dine samarbeidspartnere - både museumsfolk, politikere og vanlige bønder - fra Guizhou-provinsen i Kina der du hadde arbeidet med utvikling av økomuseer. Dette var et viktig øyeblikk for deg, en feiring av flere års arbeid med et prosjekt som kan betraktes som modell for spesielt vellykket utviklingsarbeid. Og det som gjorde dette prosjektet spesielt vellykket var at du hadde, noe som var så tydelig å se da du var sammen med dine kinesiske venner, satt menneskene i sentrum.

For deg, John Aage, var den menneskelige dimensjonen selve meningen med museumsarbeidet. Høyt profesjonelt nivå var alltid kombinert med stor generøsitet. Du ville gi en "gave" til levende mennesker, gi dem det beste du - som museumsmann - kunne, med den hensikt å få dem til å vokse.

Dette er et viktig budskap i en tid der vi - museumsfolk - blir stadig mer utsatt for en ideologi som vil få oss til å omdanne vår faglige innsikt til en "vare" som skal selges til kunder.

Marc Maure 